\title{
Editorial.
}

\section{Challenges to global financial stability: interconnections, credit risk, business cycle and the role of market participants}

\author{
Meryem Duygun, Nottingham University Business School, University of Nottingham, UK \\ meryem.duygun@nottingham.ac.uk
}

Daniel Ladley, School of Business, University of Leicester, UK, dl112@le.ac.uk

Mohamed Shaban, School of Business, University of Leicester, UK, m.shaban@le.ac.uk

\section{Introduction}

The worldwide financial crisis (WFC) of 2007-09 has shown the importance of cross-sectional dependencies of assets, credit exposures and volatility, which can threaten domestic and global financial stability through cascades in financial networks. A correct assessment of company-specific risk has to account for the potential risk spillover effects from other firms (Hautsch et al. 2014). This is because of the intertwined nature of financial markets, which allow the spread of risk throughout the system (Acemoglu et al., 2015). The potential impact of interconnected financial institutions on the entire financial system has been a financial stability concern for central banks and regulators. The need for economic foundations for a systemic risk measure is more than an academic concern since it involves regulators, supervisory authorities and policy-makers (Acharya et al. 2017). This special issue provides a substantial contribution to the systemic risk literature.

The WFC also strongly affected credit markets. A number of papers included in this special issue attempt to answer some of the main research questions related to credit markets and loan supply during crisis periods. In particular, the financial condition of banks is critically important because it may influence their ability to lend, with consequences for the wider economy (Santos, 2010). This highlights the pivotal importance of understanding the link between banks' financial condition and their lending behavior.

In the period leading up to the WFC, credit and asset prices were growing at a ferocious pace, with the ratio of debt to national income reaching 4.75:1 (Acharya and Naqvi, 2012). The subsequent house price collapse led financial markets and the real economy to the most severe recession in the post-war period (Haughwout et al., 2011). The empirical financial literature shows that this lending boom and bust cycle and subsequent collapse characterizes the business cycle in several centuries (see, for instance, Reinhart and Rogoff, 2008). Investigating the business cycle and its relationship with the real estate sector is still a core topic in the finance literature. Moreover, assessing the relationship between the business cycle and banks' capital requirements helps central banks not aware of where the economy is in the business cycle. This implies that greater emphasis needs to be placed upon the features of the real global 
financial system, considering issues related to the business cycle and real estate to which the papers included in this special issue make a strong academic and macro-prudential contribution.

The 2016 International Finance and Banking Society (IFABS) Barcelona Conference held on the 1st$3^{\text {rd }}$ of June 2016 provided a forum for such debate, including papers on a wide range of financial stability issues. Among the papers presented at the IFABS Barcelona Conference, twenty-eighth papers have been selected and published in this special issue. The papers presented here contribute to the key debates explained above and address a number of pivotal aspects and facets related to banking and finance. In particular, these papers can be categorized into four main areas: financial stability, systemic risk and networks; credit markets and loan supply; investment decisions and shareholder value; and, the business cycle and real estate.

Each paper makes a significant contribution to the financial literature and we believe that academia, regulators and supervisory authorities will benefit from reading them.

\section{Financial stability, systemic risk and networks}

The WFC and the subsequent Eurozone crisis raised significant concerns about the financial stability of national and international systems. These concerns have been reflected in an increasing number of theoretical, empirical and policy analyses investigating systemic risk and network connectedness. A number of papers included in this special issue attempt to advance the existing modelling and empirical findings related to these two topics.

In their contribution to this special issue Giudici, Sarlin and Spelta use BIS data to propose a more encompassing measure of interconnectedness that aims to capture systemic risk related to network structures by aggregating direct exposures with common exposures. They show the predictive performance of their proposed measure is superior especially in periods of financial crisis.

The paper by Zedda and Cannas looks at systemic risk and contagion determinates by means of a Leave-One-Out approach. This approach allows estimating the systemic contribution of individual banks as the sum of the stand-alone bank risk and the contagion risk. The results show that the determinants of these two types of risk are different, meaning that a bank safe with respect to stand-alone risk can be an important contagion vehicle, or vice versa. Moreover, they also show that the relationship between these two risk components is significantly affected by crisis severity.

Garratt and Zimmerman study the effects of the introduction of centralized netting in financial networks on total netted exposures between counterparties. Their results show that centralized netting increases in the expectation of net exposures, reducing the variance, with a strict subset for which expected net exposures decreases. Moreover, they find that for some network structures, the introduction of centralized netting does not beneficially affect dealers unless sufficient weight is placed on reductions in variance. Their results can be used to estimate margin requirements and counterparty risk in financial networks.

Using a Markov-switching Factor augmented VAR model, the paper of Dungey, Flavin and LagoaVarela examines the transmission of shocks between global banking, domestic banking and the nonfinancial sector for eleven Eurozone countries. Their findings show that contagion plays a role in propagating global banking shocks mainly to the domestic banking sectors without affecting the nonfinancial sector, which, however, triggers contagious effects for both the global and domestic banking sectors.

The goal of the paper by Liu, Paddrik, Yang and Zhang is to develop an agent-based model to endogenously reconstruct interbank networks on 6600 US banks' financial data. Compared to a traditional stationary network framework for contagion, results demonstrate how individual bank choices help the 
interbank lending system become more resilient to counterparty defaults and contagion. Their model formulation shows similar dynamics to those of the WFC of 2007-09 and highlights that bank losses and failures may arise also from network contagion and lending market illiquidity. Using post-crisis data from 2011 to 2014, the model documents a reduced likelihood of bank failures through network contagion and illiquidity.

Measuring banking integration with indicators that merge openness and connectedness with other banking system, Arribas, Peiró-Palomino and Tortosa-Ausina analyze the links between banking integration and different levels of economic development for a sample of OECD countries. This additional analysis is pivotal since the benefits of enhanced banking integration might not be generalizable. Results show that banking integration positively, and significantly, affects the levels of per capita income, with bank connectedness being more important for economic development than bank openness. Moreover, using quantile regressions, the authors show that these effects are stronger for the poorest economies in the sample.

Nowadays, financial firms are also expanding their business activities through social networks. The paper of Atmaca, Schoors and Verschelde investigate the relation between social networks and bank loyalty according to different states of the economy during the period from 2005 to 2012. The unique dataset built by the authors allows them to distinguish different sorts of family networks from neighborhood networks and using a proportional hazards model, the authors show the importance of family networks, especially during financial distress periods.

Systemic risk is often also related to stress test exercises, which have been introduced by the supervisory authorities to identify the systemic risk vulnerabilities of banks; and capital requirements, which have been introduced to increase the resilience of the banking and financial systems. Considering the first aspect, the paper of Fernandes, Igan and Pinheiro investigates how the annual stress tests performed by the supervisory authority affects price and trade reactions as well as information asymmetry and uncertainty indicators around the tests, and bank behavior after the tests. The results support the notion that there is important new information in stress tests, especially during crises. The public disclosure of a stress tests methodology and results, however, do not adversely affect informational asymmetries and uncertainties.

The paper of Lee, Posenau and Stebunovs represents the second contribution that aims to identify the main vulnerabilities of the financial system. This paper extends the framework proposed by Aikman et al. (2017), which uses an algorithmic approach that maps vulnerabilities in the U.S. financial system to a broader set of financial vulnerabilities in 27 advanced and emerging economies. In particular, a broader set of vulnerabilities for a panel of 30 countries is analyzed. Findings show that, while pressures in asset valuations and a build-up of imbalances in the external, financial, and nonfinancial sectors characterize the period preceding a banking crisis; these vulnerabilities subside after the crisis because of government intervention. The composite index built by the authors, which aggregate these vulnerabilities, predicts banking crises better than the credit-to-GDP gap or sector-specific vulnerability indexes and explains the variation in the severity of crises.

Taking a different view, Fidrmuc and Lind investigate the impact of higher capital requirements defined in Basel II on macroeconomic activity and analyze the ability of capital requirements to absorb systemic shocks. While the related literature reports a negative GDP effect in response to a change in the target capital ratio, their meta-regression results suggest that the estimates reported in the literature tend to be systematically influenced by a selected set of study characteristics, such as econometric specifications, the authors' affiliations, and the underlying financial system.

Bank bailouts during and after the WFC increased the debate on the effect of government support to banks. Brandao-Marques, Correa and Sapriza investigate the effects of government support using a 
sample of 321 banks rated by Moody's or Fitch Ratings. In particular, they find that government support affects the risk profile of banks by reducing market discipline and/or by increasing charter value. More importantly, restricting banks' range of activities seem to ameliorate the link between government support and bank risk taking, entailing that in the presence of moral hazard induced by government support, reducing bank complexity strengthens market discipline.

Finally, the WFC highlighted the financial importance of credit default swap (CDS) as instrument that provides the buyer with protection against default and other risks. The paper of Lovreta and Silaghi, in this special issue, analyzes the surface of CDS implied firm's asset volatility in Europe during the period from 2007 to 2014. By using principal component analysis, they show that the first four components capture $86 \%$ of the daily variation in asset implied volatility and are interpreted as a level, a term structure, a skew and a moneyness-related curvature mode. Moreover, to understand the nature of the information embedded in the asset volatility term structure, they show that the downward sloping term structure is associated with more insider trading occurring on CDS contracts with short maturities, and more demand for credit protection in the short term due to risk aversion.

\section{Credit markets and loan supply}

Financial crises affect credit markets through a reduction of the lending and borrowing activities of financial intermediaries. Indeed, a bank shortage of liquidity available for lending is just one in a series of cascading events that occur during a systemic crisis. Methodological and empirical improvements relating the relationship between financial intermediaries and customers in credit markets will help the fields understand of the evolution of credit crisis and trends, possibly reducing the related negative effects.

Considering the relationship between bankers and clients, Donker, $\mathrm{Ng}$ and Shao examine the consequences of corporate disclosure, perceived as profit warnings, as a negative information-releasing event during the normal course of business. Their findings show that profit warnings negatively affect the cost of loans, loan security and maturity. However, this effect is mainly related to the borrowing activity from non-relationship lenders. Finally, they also show that borrowers often choose to remain with their relationship bankers due to more favorable loan terms and the high costs of switching lenders. This mainly implies that relationship bankers efficiently use client information to provide effective financial intermediation.

The paper of Wang, Chiu and King investigates to what extent a firm's debt maturity structure affects the cost of bank loans. They show that the debt maturity structure is one of the major determinant of loan spreads. In addition, their results support the amplifying mechanism of rollover risk on financing costs in public debt markets. Finally, by considering different short-term debt proxies and performing various robustness tests, they show that high-growth firms experience significantly smaller increases in their loan spreads, entailing that short-term debt mitigates risk-taking incentives, leading to a decrease in firm risk.

A strong methodological improvement is introduced with the paper of Fricke and Roukny. Using detailed data on bank-firm loan interactions from Japan, the authors propose a new method based on credit networks that allows the analysis of the structure of the credit market. Their findings show a coexistence between generalist banks (with diversified lending) and specialist banks (with focused lending), which usually tend to stick to their strategies over time. The coexistence relates also to industries. This entails a strong overlap in banks' loan portfolios, mainly due to specialist banks focusing their investments on the very same generalist industries. This characteristic does not make generalist banks less vulnerable to shocks compared to specialists because of high leverage levels used by the latter.

The economic environment is affected by the evolution of the credit markets, and vice versa. Three papers in this special issue assess the relationship between key economic variables and credit markets. 
Considering a unique contracts database from a French cooperative bank between 1996 and 2009, Dereeper, Lobez and Statnik empirically show that bank-firm relationships on the credit rate depend on economic conditions. Moreover, the hold-up problem, which may result in higher interest rates, plays a role only during economic recession. The paper by Bassett, Demiralp and Lloyd empirically assesses the benefits of the US government interventions during the WFC. The main novelty of this paper is to combine an unique dataset based on five key government programs that provided debt or equity to banks in the U.S. Using an instrumental variable approach, the authors document that the lending activity did not increase at institutions receiving government support. Finally, analyzing a sample of 17,395 defaulted bank loans in USA, Great Britain, and Canada; Betz, Krüger, Kellner and Rösch study the macroeconomic and systematic frailty effects of the default resolution time. They find that frailties have a considerable impact on the resolution times, observing also that median resolution times more than double in a recession when compared to an expansion.

Banks' lending activity may be also affected by discrimination due to demographic variables, such as gender and age. The paper by Chen, Huang and $Y e$ in this special issue makes an important contribution in this direction. Using data from Renrendai, a leading Chinese peer-to-peer lending platform, they document a gender gap in the online credit market. In particular, despite findings that support that lending to female borrowers is associated with better loan performance -i.e., lower probability of default and expected loss, and higher expected profit; their results do not show any measurable gender impact on funding success rate. This entails that female borrowers have to compensate lenders with better loan performance to achieve a similar funding probability of their male peers.

\section{Investment decisions and shareholder value}

Two common themes underline the six articles in this section. In particular, three papers (Fong, Krug, Leung and Westerholm; Holod, Kitsul and Torna; and, Kolokolova, Lin and Poon) focus on investment decisions related to different market participants, such as individual investors, financial advisors, banks and hedge funds. In contrast, Nguyen, Kecskés and Mansi look at investment decisions from a shareholder perspective; while, Belkhir, Saad and Samet assess the relationship between stock extreme illiquidity and the implied cost of capital.

Using the Finnish OMX Helsinki data, the paper of Fong, Krug, Leung and Westerholm investigates the relationship between demographic variables, individual investors' broker choices and trade informativeness. Results prove to be gender dependent. In particular, men are found to use Full-ServiceRetail over Discount-Retail brokers, while women seems to be characterized by more heterogeneous broker choice behaviors. Higher levels of income lead to a higher likelihood of using Discount-Retail brokers where trades are more informative than those of Full-Service-Retail brokers. Finally, on the aggregate, women are found to make more informative trades then men. By portioning by age, this result reverses.

The paper in this special issue by Holod, Kitsul and Torna investigates whether the trading risk of banks with high trading activities have been mitigated by the market risk-based capital requirements (MRR) implemented in 1998. Implementing a difference-in-difference model, they show that only unregulated banks experienced an increase in risk associated with trading activity and in contribution of opaque trading activity to bid-ask spreads, entailing the risk-mitigating effect of the MRR for regulated banks.

Using a sample of 9725 hedge funds from 1994 to 2012, the paper by Kolokolova, Lin and Poon, in this special issue, studies the information content of aggregate hedge fund flow and its predictive power with respect to bond yields. They find a statistically significant negative relationship between fund flow and the changes in 10-year Treasury and Moody's Baa bond yields one month ahead. This suggests a non- 
trivial effect of flow-induced hedge fund trading on bond yields, which is amplified during periods of decreasing market liquidity. Additionally, their results show the predictive power of fund flows for the convergence between the constant maturity swap rate and constant maturity Treasury rate, as well as between the Treasury Inflation-Protected Securities and Treasury bond yields. This suggests that hedge funds exploit arbitrage opportunities in these fixed-income markets.

Nguyen, Kecskés and Mansi investigates the interplay between long-term investors, corporate social responsibility, and shareholder value. In particular, they study how the corporate social responsibility (CSR) affects shareholder value. Their findings show that long-term investors increase the value to shareholders of CSR activities through lower cash flow risk and that CSR activities can create shareholder value as long as long-term investors properly monitor managers.

Finally, considering an international panel made by firms located in 45 countries, Belkhir, Saad and Samet investigate the relationship between stock extreme illiquidity and the implied cost of capital. They show that firms whose stocks have a greater potential for extreme illiquidity realizations suffer from higher cost of capital. This relationship result is independent of the systematic extreme liquidity risk and is even stronger during market downturn periods, with only environments with better information quality and stronger investor protection making it weaker.

\section{Business cycle and real estate}

The WFC has been characterized by an initial exuberant in credit and asset price growth - i.e. cycle booms, and a subsequent deep recession, falling asset prices and high debt burdens, which dragged down growth. It is of fundamental importance to understand the economic business cycle, and its relationship with the real estate sector, due to the strong role played by the latter during the crisis. Purchases of real estate can allow firms to borrow more, and thus, to invest more, increasing the exposure of the real estate sector to business cycles and, at the same time, amplifying the business cycle itself (Barro, 1976, Stiglitz and Weiss, 1981, Hart and Moore, 1994). Two papers included in this section investigate the two-way relationship between the real estate sector and the business cycle (Bengtsson, Grothe and Lepers; Duca and Ling). Parsley and Popper analyze the impact of cyclical factors on a panel of 33 stock exchanges; while, Hodbod, Huber and Vasilev assess how different capital requirements amplify the business cycle.

Bengtsson, Grothe and Lepers develop a framework that transparently assesses the vulnerabilities of the residential real estate sector. Through a composite vulnerability measure, which includes three main dimension of the real estate sector vulnerabilities. The framework provides intuitive early warning signals useful for policy purposes. In particular, their vulnerability measure results in a superior significant predictor of historical real estate crises compared to the majority of alternatives in sample calibrated model-based measures.

The paper included in this special issue by Duca and Ling investigates the short- and long-run movements in the rent-to-price-ratio and risk premium for commercial real estate (CRE), which contributed to the US real estate boom and subsequently dramatic bank failures. Findings show that, during the real estate boom, CRE prices were mainly driven by declines in required risk premium, while, during the subprime financial crisis, CRE prices started to decline because of a jump in general risk premium and a tightening of effective capital requirements on commercial mortgage-backed securities from the Dodd-Frank Act. The subsequent introduction of a low interest rates environment allowed a recovery in CRE prices.

The paper by Parsley and Popper, presents a model-free co-movement measure used to analyze intra-market return co-movement within an international panel of 33 economies that have stock exchanges operating from 1995 to 2013 . They show that international macroeconomic policy instability 
and crises are important in explaining intra-market co-movement behavior. Additionally, using a much longer sample period for US firms, the authors highlight that sample compositional changes do not explain the U.S. trend, and, applying time series filters to the model-free measure of co-movement, they find that the recent upturn is at least partly due to cyclical factors.

Hodbod, Huber and Vasilev investigate how different designs of capital requirements influence the tendency of banks to amplify the business cycle. The authors compare the Basel-established Internal Ratings-Based (IRB) approach to risk-weighting assets with their macro-prudential approach that sets riskweights in response to sectoral measures of leverage. Using a general equilibrium model a boom and bust crisis scenario is analyzed. Their findings show that the IRB approach creates pro-cyclicality in regulatory capital requirements, amplifying both phases of the financial cycle, while the proposed macro-prudential approach leads to counter-cyclicality in regulatory capital requirements, attenuating the cycle.

\section{Current and future key challenges}

Three key messages emerge from the papers presented in this special issue about the future of financial stability: i) a better understanding is required of the existing relationships within interconnected financial systems to assess the systemic risk of financial firms. ii) lending activity remains core to most banks; this implies that it is important to investigate the evolution of credit markets, reducing the related negative effects on the real economy. iii) business cycles may be amplified by external factors, thus a fuller knowledge of financial instruments, sectors and macro-prudential approaches that lead to countercyclicality, attenuating the cycle, is needed.

While this special issue represents a significant contribution to the existing financial literature, we believe that more research on the themes of the special issue will be needed to develop new methodologies and tool to enhance financial stability.

\section{Acknowledgements}

We acknowledge the great support received from the JBF Editors towards this special issue. We are grateful for the research assistance of Davide Vioto and the comments and suggestions by the participants of the IFABS 2016 Barcelona Conference. 


\section{References}

Acemoglu, Daron, Asuman Ozdaglar, and Alireza Tahbaz-Salehi. "Systemic risk and stability in financial networks." American Economic Review 105, no. 2 (2015): 564-608.

Acharya, Viral V., Lasse H. Pedersen, Thomas Philippon, and Matthew Richardson. "Measuring systemic risk." The Review of Financial Studies 30, no. 1 (2017): 2-47.

Acharya, Viral, and Hassan Naqvi. "The seeds of a crisis: A theory of bank liquidity and risk taking over the business cycle." Journal of Financial Economics 106, no. 2 (2012): 349-366.

Aikman, David, Michael Kiley, Seung Jung Lee, Michael G. Palumbo, and Missaka Warusawitharana. "Mapping heat in the US financial system." Journal of Banking \& Finance 81 (2017): 36-64.

Arribas, Iván, Jesús Peiró-Palomino, and Emili Tortosa-Ausina. "Is full banking integration desirable?." Journal of Banking \& Finance, in this issue.

Atmaca, Sümeyra, Koen Schoors, and Marijn Verschelde. "Bank loyalty, social networks and crisis." Journal of Banking \& Finance, in this issue.

Barro, R., 1976. "The loan market, collateral, and rates of interest." Journal of Money, Credit and Banking, 8, 439-456.

Bassett, William, Selva Demiralp, and Nathan Lloyd. "Government support of banks and bank lending." Journal of Banking \& Finance, in this issue.

Belkhir, Mohamed, Mohsen Saad, and Anis Samet. "Stock extreme illiquidity and the cost of capital." Journal of Banking \& Finance, in this issue.

Bengtsson, Elias, Magdalena Grothe, and Etienne Lepers. "Home, safe home: cross-country monitoring framework for vulnerabilities in the residential real estate sector." Journal of Banking \& Finance, in this issue.

Betz, Jennifer, Steffen Krüger, Ralf Kellner, and Daniel Rösch. "Macroeconomic effects and frailties in the resolution of non-performing loans." Journal of Banking \& Finance, in this issue.

Brandao-Marques, Luis, Ricardo Correa, and Horacio Sapriza. "Government support, regulation, and risk taking in the banking sector." Journal of Banking \& Finance, in this issue.

Chen, Xiao, Bihong Huang, and Dezhu Ye. "Gender gap in peer-to-peer lending: Evidence from China." Journal of Banking \& Finance, in this issue.

Dereeper, Sébastien, Frédéric Lobez, and Jean-Christophe Statnik. "Bank credit rates across the business cycle: Evidence from a French cooperative contracts database." Journal of Banking \& Finance, in this issue.

Diamond, Douglas W., and Robert E. Verrecchia. "Disclosure, liquidity, and the cost of capital." The Journal of Finance 46, no. 4 (1991): 1325-1359.

Donker, Han, Alex Ng, and Pei Shao. "Borrower distress and the efficiency of relationship banking." Journal of Banking \& Finance, in this issue.

Duca, John V., and David C. Ling. "The other (commercial) real estate boom and bust: the effects of risk premia and regulatory capital arbitrage." Journal of Banking \& Finance, in this issue.

Dungey, Mardi, Thomas J. Flavin, and Dolores Lagoa-Varela. "Are banking shocks contagious? Evidence from the eurozone." Journal of Banking \& Finance, in this issue.

Fahlenbrach, Rüdiger, and René M. Stulz. "Bank CEO incentives and the credit crisis." Journal of Financial Economics 99, no. 1 (2011): 11-26. 
Fernandes, Marcelo, Deniz Igan, and Marcelo Pinheiro. "March madness in Wall Street:(What) does the market learn from stress tests?." Journal of Banking \& Finance, in this issue.

Fidrmuc, Jarko, and Ronja Lind. "Macroeconomic impact of Basel III: Evidence from a meta-analysis." Journal of Banking \& Finance, in this issue.

Fong, Kingsley, Juliane D. Krug, Henry Leung, and Joakim P. Westerholm. "Determinants of Household Broker Choices and Their Impacts on Performance." Journal of Banking \& Finance, in this issue.

Fricke, Daniel, and Tarik Roukny. "Generalists and specialists in the credit market." Journal of Banking \& Finance, in this issue.

Garratt, Rodney, and Peter Zimmerman. "Centralized netting in financial networks." Journal of Banking \& Finance, in this issue.

Giudici, Paolo, Peter Sarlin, and Alessandro Spelta. "The interconnected nature of financial systems: direct and common exposures." Journal of Banking \& Finance, in this issue.

Hart, O., Moore, J., 1994. "A theory of debt based on the inalienability of human capital." Quarterly Journal of Economics, 109, 841-879.

Haughwout, Andrew, Donghoon Lee, Joseph S. Tracy, and Wilbert Van der Klaauw. "Real estate investors, the leverage cycle, and the housing market crisis." FRB of New York Staff Report 514 (2011).

Hautsch, Nikolaus, Julia Schaumburg, and Melanie Schienle. "Financial network systemic risk contributions." Review of Finance 19, no. 2 (2014): 685-738.

Hodbod, Alexander, Stefanie J. Huber, and Konstantin Vasilev. "Sectoral risk-weights and macroprudential policy." Journal of Banking \& Finance, in this issue.

Holod, Dmytro, Yuriy Kitsul, and Gökhan Torna. "Market risk-based capital requirements, trading activity, and bank risk." Journal of Banking \& Finance, in this issue.

Kolokolova, Olga, Ming-Tsung Lin, and Ser-Huang Poon. "Too big to ignore? Hedge fund flows and bond yields." Journal of Banking \& Finance, in this issue.

Lee, Seung Jung, Kelly E. Posenau, and Viktors Stebunovs. "The Anatomy of financial vulnerabilities and banking crises." Journal of Banking \& Finance, in this issue.

Liu, Anqi, Mark Paddrik, Steve Y. Yang, and Xingjia Zhang. "Interbank contagion: An agent-based model approach to endogenously formed networks." Journal of Banking \& Finance, in this issue.

Lovreta, Lidija, and Florina Silaghi. "The surface of implied firm's asset volatility." Journal of Banking \& Finance, in this issue.

Nguyen, Phuong-Anh, Ambrus Kecskés, and Sattar Mansi. "Does corporate social responsibility create shareholder value? The importance of long-term investors." Journal of Banking \& Finance, in this issue.

Parsley, David, and Helen Popper. "Return comovement." Journal of Banking \& Finance, in this issue.

Reinhart, Carmen M., and Kenneth S. Rogoff, 2008, "Is the 2007 US sub-prime financial crisis so different? An international historical comparison." American Economic Review 98(2), 339-44.

Santos, João AC. "Bank corporate loan pricing following the subprime crisis." The Review of Financial Studies 24, no. 6 (2010): 1916-1943.

Stiglitz, J., Weiss, A., 1981. "Credit rationing in markets with imperfect information." American Economic Review, 71, 393-410.

Wang, Chih-Wei, Wan-Chien Chiu, and Tao-Hsien Dolly King. "Debt maturity and the cost of bank loans." Journal of Banking \& Finance, in this issue. 
Zedda, Stefano, and Giuseppina Cannas. "Analysis of banks' systemic risk contribution and contagion determinants through the leave-one-out approach." Journal of Banking \& Finance, in this issue. 